\title{
Análisis de la presunción de daño moral que beneficia a ciertas víctimas indirectas en la jurisdicción contencioso administrativa colombiana $a^{* * * * * *}$
}

\section{Analysis of the presumption of moral damage that benefits certain indirect victims in the administrative litigation jurisdiction in Colombia}

RESUMEN

Este artículo estudia la presunción de daño moral a favor de las víctimas indirectas en la jurisdicción contencioso administrativa. En primer término se analizan las diversas teorías en torno a la prueba del daño moral. Posteriormente se dan las razones por las cuales la prueba del daño moral de algunas víctimas indirectas corresponde a una presunción y no a un indicio. El artículo finaliza explicando las razones por las cuales la estructura de presunción conduce a indemnizar daños inciertos, además de resultar discriminatoria frente a modelos de familia no tradicionales.

PALABRAS CLAVE

Daño moral, presunción, indicio contingente, relaciones de familia, familia de hecho, derecho a la igualdad.

Magíster en Derecho con énfasis en Responsabilidad Contractual y Extracontractual Civil y del Estado de la Universidad Externado de Colombia. Investigador independiente. Bogotá, Colombia.Contacto: nicoemartinez@hotmail.com

** Recibido el 20 de febrero de 2018, aprobado el 4 de abril de 2018.

Para citar el artículo: Martínez Benavides, N. E. Análisis de la presunción de daño moral que beneficia a ciertas víctimas indirectas en la jurisdicción contencioso administrativa colombiana. En Revista Derecho del Estado, Universidad Externado de Colombia. N. ${ }^{\circ} 42$, enero-abril de 2019, pp. 181-210.

DOI: https://doi.org/10.18601/01229893.n42.07

***: Este artículo es producto de las labores desarrolladas en el marco de la línea de investigación en Responsabilidad Civil del Grupo de Derecho Privado de la Universidad Externado de Colombia. 
ABSTRACT

This article studies the presumption of non-material damage (moral damage) in favor of indirect victims in the administrative jurisdiction. The author begins the study by analyzing the various theories surrounding the proof of non-material damage (moral damage). Additionally, the author provides the reasons for which proof of the non-material damage (moral damage) of some indirect victims corresponds to a presumption and not to a clear indication. The article ends by explaining the reasons why the structure of presumption leads to compensation of uncertain damages, as well as being discriminatory against non-traditional family models.

KEYWORDS

Non-material damage, presumption, contingent indication, family relations, de facto family, equality right.

SUMARIO

Introducción. 1. Alcance de la noción de daño moral. 1.1. Teorías en torno a su prueba. 1.2. Prueba de daño moral a cargo de las víctimas indirectas en la jurisdicción contencioso administrativa colombiana. 2. Análisis crítico de la presunción. 2.1. El parentesco es solo un indicio contingente. 2.2. Concepto desactualizado de familia. 3. Consecuencias adversas de la presunción. 4. Propuesta de solución. Conclusión. Referencias.

\section{INTRODUCCIÓN}

En Colombia el daño moral es la categoría de perjuicio extrapatrimonial más antigua, cuyo reconocimiento es indiscutible por la jurisprudencia nacional. No obstante, en torno al mismo mantienen vigencia muchas discusiones, por ejemplo, las referidas a los eventos en que debe indemnizarse, la manera como debe hacerse la reparación o la manera como se ha de probar aquel.

En relación con la prueba del daño moral, la jurisdicción de lo contencioso administrativo erige una presunción a favor de algunos perjudicados de rebote y ante determinados hechos dañosos de la víctima directa (muerte, lesión y privación de la libertad), siendo suficiente, para dar por acreditado el daño moral, la prueba de la relación de parentesco.

La sentencia hito de esta línea jurisprudencial es la proferida por la Sección Tercera del Consejo de Estado el 17 de julio de 1992, en la cual aclaró que la presunción cobija, sin excepción, a quienes tengan con la víctima directa relación de parentesco hasta el segundo grado de consanguinidad. 
La presunción subsiste y es reiterada en las sentencias de unificación de la Sección Tercera del 28 de agosto de 2014, en las cuales las víctimas indirectas beneficiadas con la presunción se clasifican en niveles ( 1 y 2) con el fin de diferenciar el monto indemnizatorio.

El presente escrito aborda de manera crítica la anterior línea jurisprudencial que admite la presunción de daño moral a favor de ciertas víctimas indirectas, por considerar que la presunción, como está estructurada, es insuficiente para acreditar en grado de certeza el daño moral, además de que su aplicación es discriminatoria respecto de modelos de familia no tradicionales.

Con la anterior finalidad, en primer lugar se exponen las razones por las cuales, en estos casos, el daño moral de las víctimas indirectas se establece por medio de una presunción judicial. Lo anterior, debido a que existen autores que consideran que la presunción corresponde a un indicio, además de que en muchas providencias existe imprecisión y confusión entre ambos institutos.

Acto seguido, se analiza la estructura de la presunción de daño moral a favor de las víctimas indirectas en la jurisdicción contencioso administrativa, para finalmente dar las razones por las cuales se considera incorrecta la forma como está concebida y la aplicación de la misma por el Consejo de Estado.

\section{ALCANCE DE LA NOCIÓN DE DAÑO MORAL}

El daño moral es, entre los perjuicios extrapatrimoniales, la categoría más reconocida y aceptada en diferentes latitudes. En un principio era sinónimo de perjuicio extrapatrimonial, sin embargo, de la mano del reconocimiento de otros perjuicios extrapatrimoniales - p. ej., daño a la salud, daño a la vida de relación- se entendió que el daño moral es únicamente una especie dentro del género ${ }^{1}$.

En el ordenamiento jurídico colombiano, el daño moral llegó para quedarse a partir de su reconocimiento por la Corte Suprema de Justicia en la sentencia de casación del 21 de julio de 1922, y en la sustitutiva del 22 de agosto de 1924, proferidas en el famoso caso Villaveces ${ }^{2}$. En estas, la Corte reconoció indemnización por daño moral a favor del señor Villaveces por haber sido

1 Actualmente, la jurisdicción contencioso administrativa, a partir de las sentencias de unificación del 28 de agosto de 2014, reconoce como perjuicios extrapatrimoniales: el daño moral, el daño a la salud y el daño a bienes constitucional y convencionalmente protegidos. Por su parte, la jurisdicción ordinaria (casación civil) reconoce como especies de perjuicio no patrimonial: el daño moral, el daño a la vida de relación y el daño a bienes jurídicos de especial protección constitucional. Valga la pena aclarar que la casación civil, pese a que en algunas providencias (sentencia de 5 de agosto de 2014, exp. 11001310300320030066001) señalan igualmente el daño a la salud como categoría de perjuicio extrapatrimonial, sin embargo, nunca ha reconocido indemnización por dicho tipo de perjuicio.

2 Corte Suprema de Justicia, Sala de Casación Civil. Sentencias de 21 de julio de 1922 y de 22 de agosto de 1924. 
violentada la bóveda donde se encontraban los restos de su esposa, los cuales fueron arrojados a una fosa común.

Es decir que prontamente se cumplirá un siglo desde que el daño moral fue admitido por primera vez como un daño resarcible en Colombia y que por este (pese a que en algún tiempo la jurisprudencia lo clasificó de otra manera) $)^{3}$, se entiende un perjuicio interno-subjetivo del individuo.

En efecto, el perjuicio moral puede ser definido como aquel que impacta la órbita interna del sujeto, concretamente su esfera emotivo-espiritual, por lo que su manifestación no es única, sino que depende de la reacción de cada sujeto. No obstante, generalmente se manifiesta en forma de dolor, congoja, pesadumbre, aflicción, intranquilidad o cualquier forma de alteración emocional . Es importante precisar que la alteración emocional no puede ser patológica, pues, de serlo, se estaría frente a un daño a la salud de tipo psicológico ${ }^{4}$.

A partir de la anterior definición parecería lógico concluir que el daño moral es un perjuicio que solamente puede ser irrogado a la persona natural, en razón de que la esfera emotivo-espiritual es una característica única del ser humano; y por ende la persona jurídica, al ser incapaz de sentir, "no es susceptible de recibir daño moral puro, sino exclusivamente material"s.

El Consejo de Estado, por su parte, ha considerado que las personas jurídicas pueden reclamar indemnización por daño moral $^{6}$, e inclusive reconoció

3 En un principio la Corte Suprema de Justicia, apoyada en la clasificación de los hermanos Mazeaud y André Tunc, señaló que el daño moral podría presentarse: como una afectación al patrimonio social, concretada en el menoscabo del honor o reputación del individuo; o como una afectación al patrimonio afectivo, consistente en la lesión a sus sentimientos. Posteriormente, mediante tres sentencias del 23 de abril de 1941, de la Sala de Negocios Generales, dividió el daño moral en: daño moral subjetivo y daño moral objetivado; clasificación que igualmente adoptó en algunas providencias el Consejo de Estado, por ejemplo en sentencia del 28 de junio de 1967. Sin embargo, estas clasificaciones, por carecer de objeto y confundir el agravio moral con otras tipologías de perjuicio, no mantuvieron vigencia. Sobre el particular véase M'CAUSLAND SÁnchez, M. C. Tipología y reparación del daño no patrimonial. Situación en Iberoamérica y en la jurisprudencia de la Corte Interamericana de Derechos Humanos, Bogotá: Universidad Externado de Colombia, 2013, 64 ss.; Navia Arroyo, F. Del daño moral al daño fisiológico, ¿una evolución real? Bogotá: Universidad Externado de Colombia, 2000, 37 ss.

4 "Como se ve, el daño moral circunscribe su campo de acción a padecimientos de tipo subjetivo relacionados con el sentimiento de la víctima, por lo que se hace necesario distinguirlo del daño a la salud de carácter psíquico, problema difícil, en especial dentro del ámbito probatorio [...] [E]l daño psíquico, que se puede traducir también en una perturbación anímica, debe basarse en una alteración patológica de las funciones psíquicas del sujeto, mientras que el daño moral [...] debe quedar encerrado, por así decirlo, dentro de la subjetividad de la víctima". ConTés, É. Responsabilidad civil y daños a la persona: el daño a la salud en la experiencia italiana, ¿un modelo para América Latina? Bogotá: Universidad Externado de Colombia, 2009, 152.

5 Hinestrosa, F. Tratado de las obligaciones. 3. ${ }^{\text {a }}$ ed. Bogotá: Universidad Externado de Colombia, 2007, 532 .

6 Consejo de Estado, Sala de lo Contencioso Administrativo, Sección Tercera. Sentencia de 20 de agosto de 1993, exp. 7881. 
indemnización por daño moral a favor de la comunidad indígena La Sortija como consecuencia del homicidio de uno de sus líderes indígenas ${ }^{7}$.

Al respecto, se reitera que, a mi juicio, la persona jurídica no puede ser víctima del daño moral, debido a que la naturaleza de este excluye su existencia y resarcimiento respecto de un sujeto de derechos incapaz de experimentar algún tipo de sentimiento. De hecho, en el caso de la comunidad indígena La Sortija, lo que motivó el reconocimiento del daño moral fue la afectación a los miembros de la misma y no a la comunidad como persona jurídica ${ }^{8}$.

Adicionalmente, para el objeto del presente artículo, es necesario precisar que el daño moral presenta dos características: a) es un perjuicio o un daño consecuencia, y b) puede afectar a personas distintas de la víctima directa del hecho dañino.

Para explicar la primera característica es necesario acudir a la tesis de raigambre francesa que diferencia el daño del perjuicio 9 . Según esta, el daño corresponde a la lesión en sí misma, mientras que los perjuicios corresponden a las consecuencias que se derivan de aquel ${ }^{10}$. Así, el agravio moral no corresponde a un daño, pues para su existencia es necesaria la previa lesión, merma o afectación de otro derecho ${ }^{11}$.

Igualmente hay quienes distinguen el daño evento del daño consecuencia, en los siguientes términos: "se tiene entonces que el padecimiento de un daño a la persona, como concepto dogmático (daño evento), se puede reflejar, a su turno, en la irrogación de una serie de perjuicios consecuenciales que constituyen rubros que, en definitiva, el agente dañador deberá indemnizar (daños consecuenciales)" ${ }^{12}$.

7 Consejo de Estado, Sala de lo Contencioso Administrativo, Sección Tercera, Subsección A. Sentencia de 24 de marzo de 2011, exp. 18956.

8 "En el sub lite, no hay duda de que la comunidad La Sortija resultó afectada con la muerte de su líder indígena, hecho que debió producir gran congoja y profundo dolor entre sus miembros, pues el hoy fallecido era el representante de la comunidad y gozaba de gran respeto y admiración": Consejo de Estado, Sala de lo Contencioso Administrativo, Sección Tercera, Subsección A. Sentencia de 24 de marzo de 2011, exp. 18956.

9 "[E]l daño está constituido por el hecho o acontecimiento objetivamente verificable que reside más allá del derecho, mientras que el perjuicio atiene al derecho, y se refiere a la lesión de los derechos subjetivos patrimoniales o extrapatrimoniales": Котегсн, M. La reparación del daño como mecanismo de tutela de la persona: del daño a la salud a los nuevos daños extrapatrimoniales. Bogotá: Universidad Externado de Colombia, 2012, 113.

10 Henao Pérez, J. C. El daño: análisis comparativo de la responsabilidad extracontractual del Estado en derecho colombiano y francés. Bogotá: Universidad Externado de Colombia, 1998,76 y 77.

11 En efecto, la merma emocional propia del daño moral puede surgir a consecuencia de la afectación a la integridad personal -muerte o lesión-, de la afrenta a otro derecho de la personalidad -p. ej., libertad, honor, honra, buen nombre- o por la destrucción o pérdida total o parcial de bienes.

12 RoJAs QuiÑones, S. El daño a la persona y su reparación. Sobre la teoría general, los sistemas de cuantificación y los casos difíciles. Bogotá: Grupo Editorial Ibáñez, 2015, 203. 
Es decir que, según la primera tesis diferenciadora, el agravio moral corresponde a un perjuicio, toda vez que es una de las consecuencias que se deriva de la primera lesión a algún derecho de la personalidad e incluso patrimonial ${ }^{13}$. Y si se opta por utilizar la segunda clasificación, el daño moral es un daño consecuencia.

La segunda característica se refiere a que en esta clase de perjuicio extrapatrimonial se presenta el fenómeno del "daño reflejo, de rebote, o de contragolpe" 14 , lo que permite que sean afectados la víctima directa de la lesión y las víctimas indirectas, siendo estas últimas quienes por su cercanía y afecto con la primera pueden válidamente experimentar daño moral y, por ende, solicitar su reparación, pese a que la lesión de cual se derivó el daño moral no recayó en un derecho propio.

\subsection{Teorías en torno a su prueba}

Debido a la naturaleza intangible del daño moral, existen dos tópicos en torno a este que generan gran discusión doctrinal y jurisprudencial; el primero es su prueba y el segundo su reparación. A continuación se aborda el estudio de las teorías edificadas en torno a la prueba del daño moral, dado que lo concerniente a su reparación, en principio, escapa a la órbita de este artículo.

Sobre el particular, se pueden identificar dos teorías: una primera, según la cual el daño moral no requiere prueba, es decir que es evidente, y una segunda, opuesta a la anterior, conforme a la cual es necesaria su prueba.

Para la primera de las teorías, el daño moral no requiere ser probado dado que, por su naturaleza subjetiva e interna, la demostración de alguna afectación emotivo-espiritual resultaría imposible; por ende, es suficiente probar el hecho del cual se genera el agravio moral -p. ej., la muerte y/o lesión- para tener acreditado el daño moral ${ }^{15}$. En otras palabras, para la teoría del daño moral

13 Sobre el particular no se comparte la posición de Henao Pérez, quien se opone al reconocimiento de daño moral derivado de la destrucción total o parcial de bienes. Al respecto, se considera que sí puede reconocerse, pues de hecho el daño moral nació en Colombia por la afectación a bienes de especial afección. Así, en el caso Villaveces se reconoció daño moral, no por la muerte de la señora de Villaveces, sino por la extracción y posterior puesta en una fosa común de los restos de la misma, así como por la sustracción de la lápida y el ataúd; esto es, por la lesión a bienes materiales de especial afecto. Cfr. Henao Pérez, J. C. "Presupuestos de la responsabilidad extracontractual de los particulares y del Estado: daño contencioso y defensa de derechos". Clase magistral, Maestría en Responsabilidad Contractual y Extracontractual Civil y del Estado, Universidad Externado de Colombia. Bogotá, noviembre de 2014.

14 "En este punto y dentro de la órbita indemnizatoria del daño moral, nos referimos a los llamados daños 'por rebote' o daños indirectos, que son los daños que nacen como consecuencia del daño sufrido por otra persona, sin que se rompa el nexo de causalidad con el hecho que provocó el daño inicial”: Domínguez MARTínez, P. Daño moral derivado de muerte y de lesiones corporales. En Gómez Pomar, F. y Marín GARCÍA, I. (dirs.), El daño moral y su cuantificación. Barcelona: Bosch, 2015, 328.

15 Cárdenas Villareal, H. y González Vergara, P. Notas en torno a la prueba del daño 
evidente no es necesario probar los elementos que conforman y caracterizan esta clase de perjuicio, sino que es suficiente la prueba del hecho dañoso ${ }^{16}$.

Según esta corriente de pensamiento, por la idoneidad del hecho dañoso -principalmente cuando se trata de eventos como la muerte, lesiones, afectaciones síquicas o estéticas, y en los demás casos en los que la alteración del bienestar sea notoria ${ }^{17}$ - se considera que el mismo es prueba in re ipsa del daño moral. En palabras de Mosset Iturraspe, "el daño moral se prueba in re ipsa, vale decir se tiene por acreditada [sic] por el solo hecho de la acción antijurídica y la titularidad del accionante" 18 .

En oposición se encuentra la tesis de la necesidad de prueba del daño moral, la cual sostiene que el agravio moral ha de ser probado en los procesos judiciales de responsabilidad. Según esta postura, el daño moral es una especie de daño que, al ser el daño un elemento estructural de la responsabilidad, debe ser acreditado por quien lo invoca, so pena del rechazo de su pretensión ${ }^{19}$.

Igualmente, la doctrina que soporta esta tesis considera que el daño, en cualquiera de sus especies, es excepcional y por ende de aplicación restrictiva ${ }^{20}$. Al respecto, Diez Schwerter indica que "no existen daños morales evidentes, ni aun respecto de víctimas directas, por cuanto todo daño es excepcional y de aplicación restrictiva, no escapando a estas características el de índole moral. Su existencia, por ende, deberá ser acreditada, no obstante las dificultades que ello pueda generar" ${ }^{21}$.

\subsection{Prueba de daño moral a cargo de las víctimas indirectas en la jurisdicción contencioso administrativa colombiana}

A partir de las teorías revisadas es dable concluir que la jurisprudencia de la Sección Tercera del Consejo de Estado adopta en la actualidad un sistema mixto en relación con la prueba del daño moral de las víctimas indirectas ${ }^{22}$.

moral: un intento de sistematización. En Revista Facultad de Derecho y Ciencias Políticas. Vol. 37, . $^{\circ} 106,2007,216$.

16 Hunter Ampuero, I. La prueba del daño moral. Memoria para optar al grado de licenciado en Ciencias Jurídicas y Sociales, Universidad Austral de Chile. Valdivia, 2005, 16.

17 Stiglitz, G. y Gandolfo, A. Resarcimiento del daño moral civil, comercial y laboral, citado en Hunter Ampuero. La prueba del daño moral, cit., 17.

18 Mosset Iturraspe, J. La prueba en el proceso de daños. En Derecho de daños, citado en Hunter Ampuero. La prueba del daño moral, cit., 16.

19 Ibíd., 27.

20 Ibíd., 31.

21 Diez Schwerter, J. L. El daño extracontractual. Jurisprudencia y doctrina. Santiago: Jurídica de Chile, 1998, 146.

22 A igual conclusión se arriba en relación con las víctimas directas. Sin embargo, tal y como se anotó en la introducción del presente artículo, el mismo se ceñirá a la presunción de daño moral a favor de ciertas víctimas indirectas, pues la crítica que corresponde plantear es únicamente respecto a esta clase de víctimas. 
Es decir, en la jurisprudencia contencioso administrativa se acepta la tesis del daño moral evidente cuando quienes pretendan el resarcimiento por daño moral sean el cónyuge y los parientes de la víctima directa hasta el segundo grado de parentesco por consanguinidad o civil, cuando dicho daño es producto de la muerte, la lesión o la privación de la libertad de dicha víctima directa, debido a que no se les exige prueba de dolor, congoja, aflicción, o de cualquier forma de alteración emotivo-espiritual.

En efecto, para el reconocimiento del agravio moral se requiere en primer término la prueba del hecho dañoso - p. ej., muerte, privación de la libertad o lesión de la víctima directa-, además de la acreditación del grado de parentesco que se tiene con aquella, pues en atención a las especiales relaciones de afecto de la familia se infiere la aflicción moral.

Por el contrario, se aplicará la tesis de la necesidad de prueba del daño moral -y por ende se deberá acreditar este- si la pretensión no es incoada por el cónyuge y los parientes de la víctima directa hasta el segundo grado de parentesco por consanguinidad o civil, o si los mencionados perjudicados indirectos pretenden resarcimiento por eventos diferentes a la muerte, la privación de la libertad o la lesión de la víctima directa.

Es preciso indicar que el statu quo de la tesis del daño moral evidente en la jurisdicción contencioso administrativa fue producto de un desarrollo jurisprudencial. En un principio, sin ambages, la corporación reconoció la indemnización por agravio moral a favor de los padres e hijos de la víctima directa, únicamente, con la prueba del parentesco ${ }^{23}$; sin embargo, en relación con los hermanos se presentaron discrepancias, dado que en algunas sentencias se les reconoció daño moral con la sola prueba del parentesco ${ }^{24}$, mientras que en otras se les negó tal reconocimiento pues se consideró insuficiente tal prueba ${ }^{25}$.

La discusión fue finalmente zanjada con la sentencia del 17 de julio de 1992, en la cual, a partir del concepto de familia, consideró el Consejo de Estado que la excepción de prueba del daño moral cobija a los hermanos y, en general, a quienes en relación con la víctima directa tuviesen relación de parentesco hasta el segundo grado de consanguinidad y primero civil ${ }^{26}$.

23 Consejo de Estado, Sala de lo Contencioso Administrativo, Sección Tercera. Sentencia de 23 de abril de 1981, exp. 2040; Consejo de Estado, Sala de lo Contencioso Administrativo, Sección Tercera. Sentencia de 15 de septiembre de 1988, exp. 5212.

24 Consejo de Estado, Sala de lo Contencioso Administrativo, Sección Tercera. Sentencia de 8 de agosto de 1985, exps. acumulados 2277, 2283, 2290, 2292 y 2295; Consejo de Estado, Sala de lo Contencioso Administrativo, Sección Tercera. Sentencia de 6 de febrero de 1986, exp. 3575.

25 Consejo de Estado, Sala de lo Contencioso Administrativo, Sección Tercera. Sentencia de 26 de enero de 1989, exp 5274; Consejo de Estado, Sala Plena de lo Contencioso Administrativo. Sentencia de 7 de febrero de 1989, exp. S- 067; Consejo de Estado, Sala Plena de lo Contencioso Administrativo. Sentencia de 18 de mayo de 1990, exp. S-121.

26 Consejo de Estado, Sala de lo Contencioso Administrativo, Sección Tercera. Sentencia de 17 de julio de 1992, exp. 6750. 
El desarrollo jurisprudencial conduce a las sentencias de unificación del 28 de agosto de 2014 de la Sección Tercera del Consejo de Estado, en las cuales se dividen los perjudicados indirectos en cinco niveles, como se indica en el siguiente cuadro ${ }^{27}$.

CUADRO 1. NIVELES DE PERJUICIOS INDIRECTOS

\begin{tabular}{|l|l|l|l|l|}
\hline \multicolumn{1}{|c|}{ Nivel 1 } & \multicolumn{1}{c|}{ NIVEL 2 } & \multicolumn{1}{c|}{ Nivel 3 } & \multicolumn{1}{c|}{ NiveL 4 } & \multicolumn{1}{c|}{ NiveL 5 } \\
\hline $\begin{array}{l}\text { Relaciones } \\
\text { afectivas } \\
\text { coyugales y } \\
\text { paternofiliales }\end{array}$ & $\begin{array}{l}\text { Relación } \\
\text { afectiva del } 2^{\circ} \text { de } \\
\text { consanguinidad } \\
\text { o civil (abuelos, } \\
\text { hermanos y } \\
\text { nietos) }\end{array}$ & $\begin{array}{l}\text { Relación } \\
\text { afectiva del 3 } \\
\text { consanguinidad } \\
\text { o civil }\end{array}$ & $\begin{array}{l}\text { Relación } \\
\text { afectiva del 4 } \\
\text { consanguinidad } \\
\text { o civil }\end{array}$ & $\begin{array}{l}\text { Relaciones } \\
\text { afectivas no } \\
\text { familiares } \\
\text { terceros } \\
\text { damnificados }\end{array}$ \\
\hline
\end{tabular}

En las mencionadas providencias señala el alto tribunal que en relación con las víctimas indirectas ubicadas en los niveles 1 y 2 -cónyuge y parientes hasta el segundo grado de consanguinidad o civil ${ }^{28}$ - se requiere la prueba del parentesco, con lo cual subsiste a favor de estos la teoría del daño moral evidente; para los niveles 3 y 4 -relaciones afectivas de $3 .^{\circ}$ y $4 .^{\circ}$ grado de consanguinidad o civil- es necesaria, además, la prueba de la relación afectiva; y para el nivel 5 -terceros damnificados- se exige la prueba de la relación afectiva.

Dentro del nivel 1 el Consejo de Estado incluyó a los compañeros permanentes, con el ánimo de equiparar su situación frente a los cónyuges, si bien respecto de estos se exige la acreditación de la convivencia como prueba suficiente para la demostración del daño moral.

De otra parte, es de resaltar que la división en cinco niveles de los perjudicados indirectos tiene igualmente una finalidad indemnizatoria, pues es mayor respecto de quienes tienen con la víctima directa relaciones afectivas conyugales y paterno-filiales (nivel 1) que respecto de quienes se encuentran en el segundo grado de parentesco (nivel 2), y así sucesivamente. Es decir, existe, para el Consejo de Estado, una relación inversamente proporcional entre el parentesco entre perjudicado directo e indirecto y la indemnización a favor de este último, pues entre menor sea el grado de parentesco mayor será la indemnización.

27 Consejo de Estado, Sala de lo Contencioso Administrativo, Sala Plena de la Sección Tercera. Sentencias de 28 de agosto de 2014, exps. 26251, 27709, 28804, 28832, 31170, 31172, $32988,36149$.

28 Con ello se igualó la presunción en las distintas clases de parentesco, pues en la sentencia del 17 de julio de 1992 se extendía al segundo grado de parentesco por consanguinidad, pero en el civil solo al primero, diferencia que seguramente obedecía al rezago de la adopción simple y plena de la Ley 5. a de 1975. 


\subsubsection{Indicio o presunción}

En torno a la aplicación de la teoría del daño moral evidente en la jurisdicción contencioso administrativa colombiana, es necesario aclarar la forma como se establece dicho daño en un proceso judicial; pues, aunque mayoritariamente se considera que ello se hace a partir de una presunción judicial, parte de la doctrina considera que se determina mediante un indicio ${ }^{29}$; en particular debido a que, si bien el Consejo de Estado en la mayoría de providencias señala que corresponde a una presunción ${ }^{30}$, y en algunas ha considerado que es una prueba mediante indicios ${ }^{31}$.

Con el fin de tomar partido por una u otra postura, es decir, si la aplicación de la teoría del daño moral evidente da lugar a la aplicación de una presunción judicial o a la valoración de un indicio, o si por el contrario ambas posturas no son excluyentes, se parte del contenido de las dos nociones.

El indicio es catalogado por el régimen procesal civil (art. 165 del Código General del Proceso) como un medio de prueba, y es aquel que permite, a partir de un hecho conocido y con apoyo en las reglas de la experiencia, establecer la existencia de un hecho desconocido ${ }^{32}$.

El indicio es, entonces, un hecho, que debe estar plenamente probado en el proceso a través de cualquier medio de prueba, pero que el juez conjuga con las reglas o máximas de la experiencia para concluir sobre "la existencia o inexistencia del hecho investigado [desconocido] y si esa conclusión es cierta o únicamente probable" ${ }^{3}$.

La presunción, por su parte, según el Diccionario de la Real Academia Española, es la "acción o efecto de presumir", verbo, este último, que, según el mismo diccionario, significa "suponer o considerar algo por los indicios o señales que se tienen" ${ }^{34}$.

29 PinZÓn Muñoz, C. E. El derecho de daños en la responsabilidad extracontractual del Estado. Bogotá: Doctrina y Ley, 2015, 190.

30 Consejo de Estado, Sala de lo Contencioso Administrativo, Sección Tercera. Sentencia de 17 de julio de 1992, exp. 6750; Consejo de Estado, Sala de lo Contencioso Administrativo, Sección Tercera, Subsección C. Sentencia de 7 de julio de 2011, exp. 20835, entre otras.

31 Consejo de Estado, Sala de lo Contencioso Administrativo, Sección Tercera, Subsección B. Sentencia de 27 de septiembre de 2013, exp 29604.

32 Azula Camacho, J. Manual de derecho procesal. T. vi. Pruebas judiciales. Bogotá: Temis, 2015, 361 .

33 Devis Echandía, H. Teoría general de la prueba judicial. T. II. Bogotá: Temis, 2012, 608.

34 Real Academia Española. Diccionario de la lengua española.23. a ed. 2014. Disponible en: http://www.rae.es/rae.html 
Así, la presunción judicial ${ }^{35}$ no es un medio de prueba ni tiene "el alcance de dar por probado el hecho como tal" 36 , sino que "se trata de un procedimiento lógico al que apela el sentenciador y que se resume en la inferencia de un hecho desconocido [a partir] de otro hecho conocido [aplicando alguna regla de la experiencia]" ${ }^{37}$. Es decir, la presunción judicial es un razonamiento en el que el juez da por ciertos determinados hechos o circunstancias, sin que exista prueba directa de su ocurrencia.

Ahora bien, debido a la similitud en las definiciones de ambos institutos, mucho se ha discutido acerca de si los indicios y las presunciones judiciales son conceptos diferentes o análogos. Al respecto, se comparten las apreciaciones realizadas por Colombo, quien señala: "Indicio es el hecho real, cierto (probado o notorio), del que se puede extraer críticamente la existencia de otro hecho no comprobable por medios directos, según el material existente en el proceso. Presunción es el resultado del raciocinio en cuya virtud de la valoración de los indicios se concluye que ese otro hecho aconteció. Los indicios constituyen el presupuesto lógico de la presunción"38.

A mi juicio, si bien no son conceptos sinónimos, tampoco resultan totalmente opuestos, sino que son complementarios, pues la presunción judicial es la consecuencia -raciocinio- a la que llega el juzgador a partir de la valoración de los indicios -medios de prueba- junto con las reglas de la experiencia ${ }^{39}$.

De acuerdo con los planteamientos esbozados y viniendo a la prueba del daño moral conforme al criterio de la jurisdicción contencioso administrativa colombiana, considero que el daño moral, frente a quienes se aplica la tesis del daño moral evidente, se establece por medio de la construcción de una presunción judicial, a partir de la valoración del indicio del parentesco como hecho conocido.

35 Además de estas, se encuentran las praesumtiones iuris et de iure y iuris tantum, que son establecidas por el legislador; se diferencian en que las primeras -iuris et de iure o presunciones de derecho- no admiten prueba en contrario, por lo que son concluyentes; mientras que las segundas -iuris tantum- sí permiten que se pruebe en contra del hecho presumido, por lo que resultan supletorias.

36 RUEDA PRADA, D. La indemnización de los perjuicios extrapatrimoniales en la jurisdicción de lo contencioso administrativo de Colombia. Tesis de maestría en Derecho, Universidad del Rosario. Bogotá, 2014, 126.

37 Fenochietto, C. E. y Arazi, R. Código Procesal Civil y Comercial de la Nación, comentado y concordado. Buenos Aires: Astrea, 1983, citado en Leguisamón, V. E. Las presunciones judiciales y los indicios. 2. ed. Santa Fe: Rubinzal-Culzoni, 2006, 38.

38 Colombo, C. J. Código Procesal Civil y Comercial de la Nación, anotado y comentado. Buenos Aires: Abeledo-Perrot, 1969, citado en Leguisamón. Las presunciones judiciales y los indicios, cit., 69.

39 Señala Koteich, respecto de la prueba del daño moral en las víctimas, que "el pretium doloris, normalmente, resulta establecido con base en presunciones iuris tantum, que el juez construye a partir de los indicios aportados por las partes al proceso": Котегсн, M. La reparación del daño como mecanismo de tutela de la persona: del daño a la salud a los nuevos daños extrapatrimoniales. Bogotá: Universidad Externado de Colombia, 2012, 281. 
En efecto, el juez parte de un indicio, siendo este el parentesco, y lo conjuga con la regla de la experiencia que enseña que, por las especiales relaciones de afecto y solidaridad, los familiares resultan afectados por algún evento adverso de sus miembros, para deducir y tener por presumido el daño moral del cónyuge y los parientes hasta el segundo grado de parentesco por consanguinidad y civil, ante la muerte, la lesión y la privación de la libertad de la víctima directa.

Al respecto es necesario aclarar que la aplicación de la anterior presunción judicial no genera ningún efecto en el onus probandi regulado en el artículo 167 CGP, según el cual "incumbe a las partes probar el supuesto de hecho de las normas que consagran el efecto jurídico que ellas persiguen”, y que, en tratándose de responsabilidad del Estado, se subsume en el artículo 90 constitucional, entendiendo que para que el juez declare que el Estado debe responder patrimonialmente -efecto jurídico- será necesario que el demandante acredite un daño antijurídico y que este sea imputable al Estado por acción u omisión -supuesto de hecho- ${ }^{40}$.

A la anterior conclusión se arriba a partir de la lectura del artículo 66 CC, según el cual "se permitirá probar la no existencia del hecho que legalmente se presume, aunque sean ciertos los antecedentes o circunstancias de que lo infiere la ley, a menos que la ley misma rechace expresamente esta prueba, supuestos los antecedentes o circunstancias" ${ }^{41}$; de donde se desprende que son las presunciones legales, y únicamente estas, las que invierten la carga de la prueba respecto del hecho legalmente presumido, pues le corresponde a la parte no beneficiada con la presunción probar en contrario ${ }^{42}$.

Por ende, no pueden equipararse en sus efectos las presunciones legales a las judiciales, pues, se insiste, en estas últimas el onus probandi no sufre ninguna modificación; $y$, en efecto, para que quien demanda resulte beneficiado con la presunción judicial de perjuicio moral, además del daño sufrido por la víctima directa -p. ej., muerte, lesión o privación de la libertad-, tendrá que probar el indicio que le sirve de sustento, es decir, el parentesco, advirtiendo que es deber del juez entrar a valorar el indicio con las demás pruebas del proceso, para construir la presunción judicial en cada caso concreto ${ }^{43}$.

40 M'Causland Sánchez, M. C. Responsabilidad objetiva del Estado: tendencias, deseos y realidades. En Henao Pérez, J. C. y Ospina Garzón, A. F. (eds.), La responsabilidad extracontractual del Estado. XVI Jornadas Internacionales de Derecho Administrativo. Bogotá: Universidad Externado de Colombia, 2015, 192.

41 Igualmente, el artículo 166 CGP señala: "El hecho legalmente presumido se tendrá por cierto, pero admitirá prueba en contrario cuando la ley lo autorice".

42 M'Causland SÁnchez, M. C. Tipología y reparación del daño inmaterial. Comentarios críticos sobre la jurisprudencia reciente. Bogotá: Universidad Externado de Colombia, 2015, 74 y 75 .

43 "Así, es claro que las presunciones establecidas en la ley deben aplicarse siempre que aparezca demostrado el hecho antecedente en el cual se fundan. Tratándose de indicios, en cambio, la presunción será construida por el juez, en cada caso concreto, según su libre criterio, 
De acuerdo con lo explicado anteriormente, se procede a plantear varias críticas a la forma en que la jurisdicción contencioso administrativa le da aplicación a la presunción de daño moral a favor de las víctimas indirectas.

Sobre el particular, se reitera que, a mi juicio, en la jurisdicción contencioso administrativa el daño moral se establece a favor del cónyuge y parientes hasta el segundo grado de parentesco por consanguinidad o civil en casos de muerte, lesión y privación injusta de la libertad de la víctima directa, a partir de una presunción judicial, la cual se integra por un indicio - parentesco- y la regla de la experiencia que indica que por las especiales relaciones de afecto y solidaridad, los familiares resultan afectados por algún evento adverso de sus miembros.

\subsection{El parentesco es solo un indicio contingente}

Pese a que en el ordenamiento jurídico colombiano no existe una definición legal del parentesco, con apoyo en el Diccionario de la Real Academia Española ${ }^{44}$ puede indicarse que la noción consiste en un vínculo entre personas, el cual nace por imperio de la ley: i) entre consanguíneos (parentesco por consanguinidad, art. 35 CC); ii) entre adoptante y adoptado con ocasión de la adopción (parentesco civil, art. 50 CC), y iii) entre una persona que está casada y los consanguíneos de su pareja (parentesco por afinidad, art. $47 \mathrm{CC}$ ) ${ }^{45}$.

siempre que existan los elementos necesarios para aplicar la respectiva regla de la experiencia y no obre en el proceso otra prueba que permita concluir que se trata de una situación especial, que se aparta de la generalidad. Al respecto, debe decirse que si bien la jurisprudencia de esta Sala ha recurrido tradicionalmente a la elaboración de presunciones para efectos de la demostración del perjuicio moral, en relación con los parientes cercanos, es claro que aquéllas se fundan en un hecho probado, esto es, la relación de parentesco, de manera que a partir de ella -que constituye el hecho indicador, o el indicio propiamente dicho, según la definición contenida en el artículo 248 del Código de Procedimiento Civil-, y con fundamento en las reglas de la experiencia, se construye una presunción, que permite establecer un hecho distinto, esto es, la existencia de relaciones afectivas y el sufrimiento consecuente por el daño causado a un pariente, cuando éste no se encuentra probado por otros medios dentro del proceso. Y tal indicio puede resultar suficiente para la demostración del perjuicio moral sufrido, en la mayor parte de los casos; en otros, en cambio, pueden existir elementos de convicción en el expediente que impidan la aplicación llana de la correspondiente regla de la experiencia": Consejo de Estado, Sala de lo Contencioso Administrativo, Sección Tercera. Sentencia de 21 de septiembre de 2001, exp. 11766.

44 "Parentesco. 1. m. Vínculo por consanguinidad, afinidad, adopción, matrimonio u otra relación estable de afectividad análoga a esta. 2. m. Unión, vínculo o liga que tienen las cosas": Real Academia Española. Diccionario de la lengua española, cit.

45 Según Ramón Meza, en definición compartida por Monroy Cabra, el parentesco es la relación de familia existente entre personas. Sin embargo, dado que las relaciones de familia pueden surgir por circunstancias diferentes al parentesco, se considera errada la definición del instituto ligado al concepto de familia. En efecto piénsese en Juan, quien es hijo natural de A y B, y sin embargo es criado, mantenido y formado por $\mathrm{C}$ y su esposa, $\mathrm{D}$; por lo que cabe preguntarse: 
Según lo anterior, dado que el vínculo que existe entre cónyuges y compañeros permanentes no nace por imperio de la ley sino por voluntad propia, ya sea celebrando un contrato o por el hecho de crear una comunidad de vida permanente, es dable concluir que estos escapan a la noción de parentesco. Por lo anterior, es errado que en algunas providencias se refiera al parentesco entre cónyuges o compañeros permanentes ${ }^{46}$, pues el vínculo jurídico que los liga surge con ocasión del matrimonio o de la unión marital de hecho.

Ahora bien, los indicios, como medios de prueba, se clasifican, según su mayor o menor eficacia probatoria, en necesarios y contingentes. Sobre el particular, señala Leguisamón que serán necesarios, cuando "uno solo baste para producir el convencimiento, en razón de que supone indispensablemente el hecho indicado, por corresponder a una ley física inmutable, de causalidad necesaria, o contingentes, si apenas constituyen una inferencia de probabilidad, subdividiéndolos en graves y leves, inmediatos y próximos y mediatos o remotos, según su valor probatorio y la proximidad de la conexión entre los dos hechos" $"$.

De acuerdo con lo expuesto y retornando a la estructura de la presunción de daño moral a favor de las víctimas indirectas en la jurisdicción contencioso administrativa, considero que el indicio sobre el cual se funda aquella, esto es, el parentesco o estatus de cónyuge, es simplemente un indicio contingente.

En efecto, el daño moral envuelve un impacto emocional negativo para quien lo sufre, mientras que el parentesco o estatus de cónyuge constituye prueba del vínculo jurídico que existe entre dos personas, pero no necesariamente plantea una relación de afecto entre los mismos del cual pudiese desprenderse un impacto emocional a cargo del perjudicado indirecto por un evento adverso ocurrido a la víctima directa. Al respecto señala Vergara Bezanilla:

Suele acontecer, asimismo, que en los casos de daño moral causado a los parientes, se lo dé por establecido sobre la base de suponer, por el solo hecho del vínculo

¿cuál es la familia de Juan? Lo serán sus parientes -padres- o, por el contrario, quienes pese a no tener grado de parentesco alguno fueron quienes velaron por él toda su vida. A mi juicio, la familia de Juan corresponderá a aquellos con quienes está unido por lazos de afecto o solidaridad, y no simplemente de consanguinidad o jurídicos. Meza Barros, R. Manual de derecho de familia. Santiago: Jurídica de Chile, 1975, 12, citado en Monroy Cabra, M. G. Derecho de familia, infancia y adolescencia. Bogotá: Librería Ediciones del Profesional, 2014, 45.

46 "Cuando ha tratado el tema de la prueba de la existencia de los perjuicios morales en los parientes del afectado, esta Corporación ha considerado que el hecho de que esté acreditado el parentesco representa un indicio para la configuración de ese daño en los parientes hasta el segundo grado de consanguinidad y primero civil, esto es, respecto de los padres, hermanos, abuelos e hijos del afectado y de su cónyuge o compañera permanente": Consejo de Estado, Sala de lo Contencioso Administrativo, Sección Tercera, Subsección B. Sentencia de 30 de junio de 2011, exp. 19836.

47 Leguisamón. Las presunciones judiciales y los indicios, cit., 100. 
de parentesco, la existencia del afecto y de la unidad familiar entre la víctima y las personas que reclaman la indemnización. Esto es del todo improcedente, ya que tal suposición es ficticia. [...]

Tan es así, que el Código Penal describe diversas figuras penales basadas, precisamente, en la deslealtad familiar y en la ruptura de la unidad y del afecto entre parientes (aborto, abandono de los hijos, adulterio, lesiones, parricidio, etc.); y que también las leyes civiles son expresivas en demostrar las desarmonías y rupturas que suelen existir entre cónyuges y entre padres e hijos. Recuérdense las causales de divorcio (malos tratamientos, autoría, instigación o complicidad en la perpetración o preparación de un delito contra los bienes, la honra o la vida del otro cónyuge, el abandono del hogar, etc.), y las de emancipación judicial (maltrato habitual del hijo, en términos de poner en peligro su vida o de causarle grave daño, abandono del hijo, etc.), sin mencionar también las reglas relativas al derecho de alimentos que están basadas en el incumplimiento del deber de socorro entre personas ligadas por vínculos cercanos de parentesco. Todo esto permite afirmar que es tan irreal suponer, a priori, que las relaciones de familia están siempre marcadas por el afecto y la unidad familiar, como suponer lo contrario ${ }^{48}$.

El parentesco o el estatus de cónyuge demuestran únicamente la relación jurídica existente entre dos personas, pero del mismo no se deducen obligatoriamente relaciones de afecto entre aquellos. Las relaciones de afecto no tienen una correspondencia con las relaciones jurídicas, pues, pese a que estas existan, aquellas puede que nunca hayan existido: piénsese en familiares que no se conocen o en matrimonios por conveniencia migratoria; o incluso en aquellos que no se mantengan, con ocasión de una discusión o ante alguna separación de hecho de los cónyuges.

No se pretende en este punto sostener que entre personas vinculadas por lazos de parentesco reina el odio y la cizaña; lo que aquí se sostiene es que no puede de dicha circunstancia deducirse, sin ninguna otra consideración, afecto $^{49}$. El mismo Instituto Colombiano de Bienestar Familiar señala que

48 Vergara Bezanilla, J. P. La mercantilización del daño moral. En Revista de Derecho del Consejo de Defensa del Estado. N. ${ }^{\circ}$ 1, 2000, 71.

49 La crítica tampoco se dirige contra la regla de la experiencia según la cual, en atención a las relaciones de cercanía y afecto que rodean la familia, el sufrimiento o evento adverso de sus miembros repercute sobre los demás. El afecto entre familiares siempre será la regla general, solo que no puede preestablecerse frente a quien se siente afecto, toda vez que el amor, la solidaridad y la cercanía penden de factores diferentes a un vínculo jurídico. Al respecto, el mismo Consejo de Estado ha aceptado que "la familia no se configura sólo a partir de un nombre y un apellido, y menos de la constatación de un parámetro o código genético, sino que el concepto se fundamenta, se itera, en ese conjunto de relaciones e interacciones humanas que se desarrollan con el día a día, y que se refieren a ese lugar metafísico que tiene como ingredientes principales el amor, el afecto, la solidaridad y la protección de sus miembros entre sí, e indudablemente también a factores sociológicos y culturales". Consejo de Estado, Sala de lo Contencioso Administrativo, Sección Tercera. Sentencia de 2 de septiembre de 2009, exp. 17997. 
"[1]os vínculos afectivos se entienden como aquellas relaciones de cariño y amor que existen entre las personas" y que "van más allá de los lazos de parentesco" 50 .

Si del parentesco se derivara amor, cercanía y afecto, no existirían estadísticas sobre abandono de menores o violencia intrafamiliar; pero es otra la realidad. Según el World Family Map, el porcentaje de menores que vive en hogares sin ninguno de sus padres oscila entre el $4 \%$ en Argentina y el $20 \%$ en Sudáfrica y Uganda. En relación con Colombia, se señala como el país sudamericano con mayor porcentaje de niños que viven sin ninguno de sus padres, con el $11 \%^{51}$.

Por ende, si de los mencionados estatus jurídicos no es dable concluir indefectiblemente relaciones de afecto o cercanía, mucho menos pueden tomarse aquellos como indicios necesarios de un agravio moral a favor de los perjudicados indirectos ante la muerte, lesión o privación de la libertad de la víctima directa.

\subsection{Concepto desactualizado de familia}

La segunda crítica que corresponde formular a la presunción de daño moral de las víctimas indirectas se hace a partir del concepto de familia utilizado para darle aplicación a la regla de la experiencia.

En esa óptica es necesario conceptualizar la familia, tarea que resulta compleja debido a que corresponde a una noción social, por lo que su caracterización dependerá de la sociedad ante la cual se esté. Al respecto, señala Hinestrosa que la familia es un "vocablo único y equívoco, como el que más. Al solo escucharlo o leerlo, todos sabemos de qué se trata. Sólo que no significa lo mismo en todos los lugares, ni en todos los hogares" ${ }^{52}$.

Pese a lo anterior, se intentará desentrañar la noción de familia consagrada en el ordenamiento jurídico colombiano. Sobre la institución pueden identificarse dos regulaciones contrapuestas, la del Código Civil y la de la Constitución.

El Código Civil, dada la época de su expedición (1887), reguló un modelo conservador de familia, y pese a que no define la familia, se puede indicar

50 Instituto Colombiano de Bienestar Familiar. Entornos protectores. Módulo 5: Vinculación afectiva. 2. ed. 2017, 9. Disponible en: https://www.icbf.gov.co/sites/default/files/ procesos/pu5.mo9_.pp_modulo_5_vinculacion_afectiva_v2.pdf

51 Child TREnds. World Family Map. Mapa de los cambios en la familia y consecuencias en el bienestar infantil, 2015, 11. Disponible en: http://worldfamilymap.ifstudies.org/2015. Relacionado con esto, diariamente fueron abandonados tres menores de edad en 2016 en Colombia: Aldeas Infantiles sos Colombia. Abandono: un delito injustificable, 2016, 1. Disponible en: http://www.agenciapandi.org/wp-content/uploads/2015/Reportajes/Abandono_Ninez.pdf

52 Hinestrosa, F. Hacia un derecho de familia del siglo XXI. En Revista de Derecho Privado, Universidad Externado de Colombia. N. ${ }^{\circ} 4,1999,4$. 
que "el modelo de familia amparado por tal normatividad es el monogámico heterosexual y, en segundo lugar, [que] la familia surge, a los ojos de tal estatuto, una vez celebrado el matrimonio" ${ }^{53}$.

Por otro lado, la regulación que de la familia trajo la Constitución de 1991 es armónica con el Estado social de derecho de carácter pluralista que estatuye su artículo $2^{\circ}$. En efecto, en el artículo 42 se define a la familia como el núcleo fundamental de la sociedad y, contrario a la regulación del Código Civil, no se consagra un modelo de familia monogámico-heterosexual, y su conformación no surge únicamente por el hecho del matrimonio ${ }^{54}$.

Adicionalmente, el artículo 42 ibídem indica que la familia "se constituye por vínculos naturales o jurídicos, por la decisión libre de un hombre y una mujer de contraer matrimonio o por la voluntad responsable de conformarla".

En relación con este artículo, autores como González Medina ${ }^{55}$ y Araújo Rentería ${ }^{56}$ consideran que su lectura permite una interpretación según la cual la familia puede surgir: i) por vínculos naturales o jurídicos, ii) por la decisión libre de un hombre y una mujer de contraer matrimonio y iii) por la voluntad responsable de conformarla.

Es decir, la Constitución de 1991 amplió la noción de familia en Colombia, dado que se alejó de instituciones tradicionales y formalistas como el matrimonio. Dentro de esa concepción han surgido modelos familiares como la denominada familia de hecho o de crianza, la cual se caracteriza porque "las personas [que la integran] no están unidas única y exclusivamente por vínculos jurídicos o naturales, sino por situaciones de facto, caracterizadas y conformadas a partir de la convivencia y en virtud de los lazos de afecto, solidaridad, respeto, protección y asistencia" ${ }^{57}$.

El Consejo de Estado inclusive ha reconocido en varias providencias la importancia de las relaciones de crianza en el momento de valorar la indemnización de perjuicios de los perjudicados indirectos.

Ejemplo de ello es la sentencia del 9 de marzo de 2011 en la cual la Subsección A de la Sección Tercera del Consejo de Estado otorgó indemnización por daño moral en calidad de hermano de la víctima directa a quien, pese a encontrarse en el cuarto grado de parentesco (primo), logró demostrar que la víctima directa "convivía con ellos desde los dos años de edad, por esa razón fue considerado como un hijo más, y han velado por su bienestar desde entonces" 58 .

53 González Medina, D. A. Familia e igualdad. Dos conceptos relacionados a la luz de la Constitución Política de 1991. En Revista Derecho del Estado, Universidad Externado de Colombia. N. ${ }^{\circ} 19,2006,74$.

54 Ibíd.

55 Ibíd.

56 Corte Constitucional. Sentencia C-814 de 2001, salvamento de voto.

57 Corte Constitucional. Sentencia T-606 de 2013.

58 Consejo de Estado, Sala de lo Contencioso Administrativo, Sección Tercera, Subsección A. Sentencia de 9 de marzo de 2011, exp. 18587. 
Igualmente, en dos de las sentencias de unificación del 28 de agosto de 2014 se reconoció la importancia de las relaciones de facto. En una de ellas se reconoció y ubicó en el segundo nivel indemnizatorio a quienes eran identificados como "abuelos" de las víctimas directas por varios testigos, pese a no demostrar el parentesco con la víctima directa ${ }^{59}$. En otra, la Sección Tercera reconoció que lo importante en el momento de reconocer daño moral es "la existencia de la relación afectiva entre la víctima y las demandantes”, y a partir de allí ubicó en el segundo nivel indemnizatorio a quien no contaba con prueba idónea del estado civil, pero demostró la relación afectiva con la víctima directa por otros medios ${ }^{60}$.

Aclarada así la noción de familia que actualmente existe en el ordenamiento jurídico y su aceptación por el Consejo de Estado, se debe comparar con la noción de familia sobre la cual se fundamenta la regla de la experiencia que alimenta la presunción de daño moral de los perjudicados indirectos en la jurisdicción contencioso administrativa.

Con esa finalidad, se remite a la sentencia del 17 de julio de $1992^{[61]}$ con la cual la Sección Tercera del Consejo de Estado sentó su posición acerca de que el daño moral se presume a favor de quienes se encuentren respecto de la víctima directa en el primer grado civil y el segundo de consanguinidad.

En esta sentencia, la Sección Tercera, luego de estudiar el concepto de familia a la luz del artículo 42 de la Constitución, junto con algunos artículos del Código Civil, indicó:

La familia para fines de las controversias indemnizatorias, está constituida por un grupo de personas naturales, unidas por vínculos de parentesco natural o jurídico, por lazos de consanguinidad, ofactores civiles, dentro de los tradicionales segundo y primer grados señalados en varias disposiciones legales en nuestro medio.

Así las cosas, la Corporación varía su anterior posición jurisprudencial, pues ninguna razón [hay] para que en un orden justo se continúe discriminando a los hermanos, víctimas de daños morales, por el hecho de que no obstante ser parientes en segundo grado, no demuestran la solidaridad o afecto hasta hoy requeridos, para indemnizarlos. Hecha la corrección jurisprudencial, se presume que el daño antijurídico inferido a una persona, causado por la acción u omisión de las autoridades públicas genera dolor y aflicción entre sus parientes hasta el segundo grado de consanguinidad y primero civil, ya sean ascendientes, descendientes o colaterales. (Resaltado fuera de texto).

59 Consejo de Estado, Sala de lo Contencioso Administrativo, Sala Plena de la Sección Tercera. Sentencia de 28 de agosto de 2014, exp. 32988.

60 Consejo de Estado, Sala de lo Contencioso Administrativo, Sala Plena de la Sección Tercera. Sentencia de 28 de agosto de 2014, exp. 26251.

61 Consejo de Estado, Sala de lo Contencioso Administrativo, Sección Tercera. Sentencia de 17 de julio de 1992, exp. 6750. 
Como se observa, el Consejo de Estado no le da al concepto de familia el alcance constitucional que actualmente tiene la noción y, por el contrario, se funda en criterios tradicionales para señalar que la familia "para fines de las controversias indemnizatorias, está constituida por un grupo de personas naturales, unidas por vínculos de parentesco natural o jurídico, por lazos de consanguinidad, o factores civiles".

Ahora bien, en las sentencias de unificación del 28 de agosto de 2014 la Sección Tercera del Consejo de Estado no señala de forma concreta un concepto de familia, no obstante lo cual puede igualmente concluirse que en dichas providencias la noción se fundamenta en elementos formales.

Esto se deduce cuando en el nivel 5 ubica a los terceros damnificados, siendo estos quienes no tienen vínculo de parentesco con el perjudicado directo, y frente a los cuales señala que su relación afectiva no es familiar; esto, como si las relaciones familiares únicamente dependieran del parentesco, lo cual no es correcto, como se sostiene a lo largo de este trabajo.

Al comparar entonces el concepto de familia sobre el cual el Consejo de Estado fundó la presunción de daño moral a favor de las víctimas indirectas, con el concepto de familia acorde a los parámetros de la Constitución Política de 1991, es fácil concluir que la jurisdicción contencioso administrativa se basa en una noción desactualizada, pues se funda en elementos eminentemente formales.

\section{CONSECUENCIAS ADVERSAS DE LA PRESUNCIÓN}

Precedentemente se expusieron las objeciones a la presunción de daño moral a partir de los elementos configurativos de la misma, el parentesco como indicio y el concepto de familia sobre el cual se finca la regla de la experiencia.

Con base en dichas críticas, acto seguido se exponen las consecuencias adversas que conlleva la aplicación de la presunción, en la forma como actualmente funciona la misma.

En primer lugar, el Consejo de Estado establece de manera general una presunción de hombre a favor de algunas víctimas indirectas, pasando por alto que las presunciones judiciales deberían establecerse en cada caso concreto atendiendo las particularidades del mismo.

Las presunciones judiciales tienen como función servirle al juez para la correcta valoración de las pruebas ${ }^{62}$. Sin embargo, dado que la presunción de daño moral a favor de las víctimas indirectas está preestablecida y se aplica de forma general, se incumple tal función, pues homogeneiza los procesos judiciales, perdiendo de vista que cada proceso constituye un universo particular.

62 Devis Echandía, H. Teoría general de la prueba judicial. T. 2. 6. ${ }^{\text {a }}$ ed. Bogotá: Temis, 2012,678 . 
La anterior circunstancia, esto es, que la presunción opere de forma general, conduce a que la declaratoria del daño moral a favor de los perjudicados indirectos no se sustente, como debería, en las pruebas de cada proceso, y que la certeza del daño, como condición para su existencia, quede en entredicho.

El daño es el elemento central en torno al cual gira un juicio de responsabilidad, y para que pueda hallarse configurado debe reunir varios requisitos o condiciones de existencia. Uno de estos requisitos es la certeza del mismo, por oposición a la contingencia o eventualidad respecto de su causación.

En palabras de Tamayo, "el daño es cierto cuando a los ojos del juez aparece con evidencia que la acción lesiva del agente ha producido o producirá una disminución patrimonial o moral en el demandante" ${ }^{63}$. Según lo anterior, para que pueda indemnizarse el daño moral, y en general cualquier clase de daño, no debe existir duda respecto de su causación, pues de lo contrario se estaría indemnizando un daño simplemente eventual, generando un enriquecimiento injustificado a favor del demandante.

Ahora bien, contrastando la anterior condición de existencia del daño con la presunción de daño moral a favor de las víctimas indirectas, se puede concluir que, en la forma como está estructurada la presunción, se están indemnizando daños morales hipotéticos y eventuales por parte de la jurisdicción contencioso administrativa.

En efecto, como se explicó, la presunción se basa en un único indicio, esto es, el parentesco, el cual es, respecto del daño moral, simplemente un indicio contingente, toda vez que no se puede deducir indefectiblemente cariño y afecto de quienes se encuentran vinculados por dicha situación jurídica.

Al ser simplemente un indicio contingente y fundamentar la presunción sobre el mismo, se vulnera la regla según la cual la eficacia probatoria de los indicios contingentes pende de su pluralidad, pues un único indicio contingente "solo representa un argumento de probabilidad, más o menos mayor según las circunstancias de cada caso, de la existencia o inexistencia del hecho desconocido que se investiga" ${ }^{64}$, pero no da certeza del hecho ${ }^{65}$.

Ese requisito encuentra soporte en el ordenamiento nacional en el artículo 242 CGP, cuando enseña que los indicios se apreciarán en conjunto, y además establece que deben ser graves, concurrentes y convergentes, en razón de que:

63 Tamayo Jaramillo, J. Tratado de responsabilidad civil. T. 2. 2. ed. Bogotá: Legis, 2015,339 .

64 Devis Echandía. Teoría general de la prueba judicial, cit., 636.

65 "Tratándose de indicios de esta clase que hemos calificado de vehementes, y que algún autor llama necesarios, basta, pues, uno solo para establecer ciertamente un hecho. Cuando los indicios no revisten este carácter se necesitará el concurso de varios para llegar a la certeza, no pudiéndose racionalmente fijar número alguno mínimo, necesario y suficiente para producir la convicción. Ese número variará según las circunstancias de cada caso, según la fuerza o peso de los indicios que entran en la combinación”. Dellepiane, A. Nueva teoría general de la prueba. Bogotá: Temis, 1961, 106 ss., citado en Devis Echandía. Teoría general de la prueba judicial, cit., 639 . 
... [los] indicios se pesan y no se cuentan, no basta que aparezcan probados en número plural; es indispensable que examinados en conjunto produzcan la certeza sobre el hecho investigado y que, para que esto se cumpla, se requiere que sean graves, que concurran armónicamente a indicar el mismo hecho y que suministren presunciones que converjan a formar el convencimiento en el mismo sentido ${ }^{66}$.

Por otra parte, el que la presunción se erija sobre un concepto tradicional de familia conduce a que la misma beneficie únicamente a quienes se encuentran dentro de dicha noción, vulnerando el derecho a la igualdad de quienes conforman otro tipo de familia. Piénsese, por ejemplo, en una familia de crianza que pierde a uno de sus miembros por una causa imputable al Estado. Al acudir a la jurisdicción a reclamar los perjuicios morales, aquellos no se encontrarán cobijados por la presunción y, por el contrario, les corresponderá demostrar sus relaciones familiares, al igual que el dolor, la congoja o cualquier tipo de aflicción emocional con ocasión de la muerte de su familiar.

En otras palabras, la presunción de daño moral se establece frente a un modelo de familia tradicional y su prueba se da mediante elementos formales como el parentesco por medio del registro civil; lo anterior conduce a que respecto de modelos de familia no tradicionales, como la de hecho o crianza, no opere la presunción, toda vez que no poseen la formalidad exigida.

Lo anterior resulta discriminatorio, debido a que, acorde al artículo 13 de la Constitución, todos los modelos familiares merecen igual tratamiento, tal y como lo ha señalado la Corte Constitucional:

El pluralismo y la evolución de las relaciones humanas en Colombia, tiene como consecuencia la formación de distintos tipos de familias, diferentes a aquellas que se consideraban tradicionales, como lo era la familia biológica. Por lo que es necesario que el derecho se ajuste a las realidades jurídicas, reconociendo y brindando protección a aquellas relaciones familiares en donde las personas no están unidas única y exclusivamente por vínculos jurídicos o naturales, sino por situaciones de facto, las cuales surgen en virtud de los lazos de afecto, solidaridad, respeto, protección y asistencia. La protección constitucional a la familia se extiende tanto a las familias conformadas en virtud de vínculos jurídicos o de consanguinidad, como a aquellas que surgen de facto, "atendiendo a un concepto sustancial y no formal de familia" donde conceptos como la convivencia, el afecto, la protección, el auxilio y respeto consolidan el núcleo familiar, por lo que el ordenamiento jurídico debe reconocer y proteger a los integrantes de tales familias ${ }^{67}$.

Por otra parte, y debido a que el monto de la indemnización está directamente relacionado con el grado de parentesco, más allá de la cercanía con la víctima directa y de la intensidad del daño padecido, en algunas providencias el

66 Ibíd.,p. 640.

67 Corte Constitucional. Sentencia T-070 de 2015. 
Consejo de Estado decidió reconocer como tercero damnificado e indemnizar en tal calidad al padre de crianza o padrastro de los demandantes ${ }^{68}$, cuando lo justo era otorgar indemnización en calidad de padre, la cual es mayor a la que se recibe como tercero damnificado.

En otras decisiones, pese a haber encontrado demostrada la cercanía, afecto y congoja por otros medios probatorios, el Consejo de Estado decidió indemnizar igualmente como terceros damnificados a quienes no demostraron en debida forma su parentesco con la víctima indirecta ${ }^{69}$.

Lo anterior demuestra cómo el atar la presunción de daño moral a un estatus jurídico y a la prueba del mismo repercute igualmente en el monto indemnizatorio reconocido, pues en algunos eventos se ha obviado la realidad probatoria del caso concreto.

Finalmente, la presunción preestablecida de daño moral "permite" a la entidad demandada probar en contrario ${ }^{70}$, para lo cual podrá atacar la presunción; ya sea refutando la veracidad del indicio contingente, esto es, "demostrando la inexistencia o debilidad de la relación familiar en que se sustentan" "71, o tachando de falso el registro civil allegado, o rebatiendo el hecho presumido; esto es, podrá demostrar que la víctima indirecta no sufrió ningún daño moral.

68 "En el caso del actor Tomás Ducuara, la prueba testimonial acreditó la condición que alegó como padrastro de la víctima, así como su padecimiento y aflicción con ocasión [de] la privación injusta de la libertad de la cual fue objeto el señor José Arnoldo Pérez; así, se le indemnizará el perjuicio moral, como tercero damnificado, esto es, el equivalente a siete punto cinco (7.5) salarios mínimos legales mensuales vigentes". Consejo de Estado, Sala de lo Contencioso Administrativo, Sección Tercera, Subsección A. Sentencia de 26 de abril de 2017, exp. 44451; "Por lo tanto, se tasará la indemnización a favor de la señora María González, en calidad de madre[,] y de la señora Ilda Luceth Morales Ramos, en calidad de compañera permanente, en 100 salarios mínimos legales mensuales vigentes, a cada una, y a favor de Luz Mila González y Alba Nelly González, en calidad de hermanas[,] en 50 salarios mínimos legales mensuales vigentes, a cada una. Frente a los terceros damnificados, esto es, los señores Francisco Zabala (padre de crianza); Elver, Marily, Luis y Jhon González y Charles Mauricio Morales Ramos y Lyda Yesenia Morales Ramos[,] se les otorgará 30 s.m.L.M.v. a cada uno". Consejo de Estado, Sala de lo Contencioso Administrativo, Sección Tercera, Subsección B. Sentencia de 29 de agosto de 2013, exp. 29707.

69 Consejo de Estado, Sala de lo Contencioso Administrativo, Sección Tercera, Subsección A. Sentencia de 10 de mayo de 2017, exp. 44080; Consejo de Estado, Sala de lo Contencioso Administrativo, Sección Tercera, Subsección A. Sentencia de 25 de enero de 2017, exp. 45057; Consejo de Estado, Sala de lo Contencioso Administrativo, Sección Tercera, Subsección A. Sentencia de 29 de octubre de 2014, exp. 29626; Consejo de Estado, Sala de lo Contencioso Administrativo, Sección Tercera, Subsección A. Sentencia de 29 de junio de 2013, exp. 29452; Consejo de Estado, Sala de lo Contencioso Administrativo, Sección Tercera, Subsección B. Sentencia de 30 de enero de 2013, exp. 25583.

70 RUEDA PRADA. La indemnización de los perjuicios extrapatrimoniales en la jurisdicción de lo contencioso administrativo de Colombia, cit., 129.

71 Consejo de Estado, Sala de lo Contencioso Administrativo, Sala Plena de la Sección Tercera, sentencia de 23 de agosto de 2012, exp. 24392. 
Si bien no puede considerarse que se está frente a una prueba diabólica a cargo de la entidad pública, lo cierto es que la posibilidad de que la entidad refute la presunción es remota debido a que desconoce los antecedentes y condiciones familiares de los "afectados"

Así, se encuentra acertada la postura de Tamayo Jaramillo cuando señala que si al demandado se le permite desvirtuar la presunción, por lógica se entiende que el daño moral sí puede ser demostrado por quien lo sufrió, y que incluso es "más fácil demostrar la existencia del daño que su inexistencia, pues el demandante posee mayores elementos de prueba que el demandado"73. Adicionalmente, en virtud de la facilidad y cercanía con los medios de prueba, debería ser el demandante quien asumiera dicha carga, según lo dispuesto en el artículo 167 CGP.

\section{PROPUESTA DE SOLUCIÓN}

Se considera en el presente trabajo que la solución a la disfuncionalidad que existe en la presunción de daño moral a favor de las víctimas indirectas consiste en que la misma se realice en cada caso concreto atendiendo los siguientes parámetros.

Como ya se mencionó, en tratándose de presunciones de hombre, la carga de la prueba no sufre modificación alguna, y por ende le corresponde a quien solicita indemnización de perjuicios arrimar los medios de convicción para que el juez pueda realizar, de forma correcta, la presunción ${ }^{74}$.

72 "Se incurre, además, en una suerte de inversión del peso de la prueba, pues se hace recaer en el demandado la prueba del hecho negativo de no haber existido el daño moral; lo que es, también, injusto, ya que normalmente aquel no ha tenido vinculación alguna anterior con el actor y, en consecuencia, ignora las condiciones personales y familiares de éste, haciéndole materialmente imposible controvertir sus pretensiones, aunque los hechos en que éstas se apoyan carezcan de fundamento en la realidad". Vergara Bezanilla. La mercantilización del daño moral, cit., 7167-7177.

73 Tamayo Jaramillo. Tratado de responsabilidad civil, cit., 811.

74 "[E]l mecanismo de la presunción del daño moral es perfectamente factible, en tanto sean las partes las que proporcionen al juez los hechos que le permitan a partir de un hecho conocido (el hecho fáctico proporcionado por el actor), arribar a uno desconocido -y pretendido- como lo es el daño moral que pueda haber sufrido el demandante, conforme se ha expuesto anteriormente. Esto por lo demás permitiría morigerar las nefastas consecuencias a las que habría de arribar la cuestión, particularmente en materia de indemnización por rebote, por cuanto será necesario acreditar la relación real o el vínculo afectivo verdadero entre la víctima y sus familiares. Ahora bien, para cuidar la función que el moderno derecho de daños atribuye a la responsabilidad civil, en tanto la mirada y el acento han sido puestos en la víctima, atendiendo en consecuencia a su reparación, más que al reproche que habrá de hacerse al victimario, es gravitante hacer notar que lo que se requiere no es una prueba exacta de los perjuicios sufridos por la víctima, sino que se proporcionen los medios probatorios suficientes que permitan formar convicción en el sentenciador de que se ha padecido un perjuicio de esa naturaleza". Femenias Salas, J. Notas sobre la prueba del daño moral en la responsabilidad civil. En Revista Derecho y Humanidades, Pontificia Universidad Católica de Chile. N. ${ }^{\circ}$ 17, 2011, 41. 
Valga la pena aclarar que, dada la libertad probatoria que rige nuestro sistema de prueba judicial, el demandante puede demostrar con cualquier medio de prueba el vínculo existente entre víctima directa e indirecta.

Así, se comparte una de las críticas planteadas por M'Causland Sánchez a las sentencias de unificación del 28 de agosto de 2014 del Consejo de Estado, crítica según la cual, debido a la libertad probatoria, no es razonable exigir prueba del parentesco, por lo que "cualquiera de las pruebas idóneas aportadas por el demandante para demostrar la relación afectiva existente entre él y la víctima, y el sufrimiento consecuente, la tendrá que decretar y valorar el juez en el caso concreto"75.

Lo importante es probar el grado de cercanía y estrecha relación que exista con el afectado directo, mas no el vínculo jurídico que se tiene con este. De allí que los Principios de Derecho Europeo de la Responsabilidad Civil (Principles of European Tort Law, PETL) y el Marco Común de Referencia para el derecho privado europeo (Draft Common Frame of Reference, DCFR) hagan alusión a los términos personas allegadas (close persons) y relación personal cercana (close personal relationship) para legitimar la indemnización de daños inmateriales a víctimas indirectas, con lo cual flexibilizan el reconocimiento de perjuicios acorde a la realidad fáctica, por encima de la seguridad jurídica que otorga preestablecer qué parientes tienen derecho a recibir indemnizaciones no pecuniarias ${ }^{76}$.

Adicionalmente, el juez debe aplicar la regla según la cual los indicios se estudian de forma conjunta. En efecto, el artículo 242 CGP reza: "El juez apreciará los indicios en conjunto, teniendo en consideración su gravedad, concordancia y convergencia, y su relación con las demás pruebas que obren en el proceso". De la anterior norma se desprende la necesidad de una pluralidad de indicios para fundamentar la decisión judicial.

En este orden de ideas, para que se decrete la presunción de daño moral a favor de una víctima indirecta es necesario que la decisión se sustente en varios indicios, y no en solo uno, como actualmente opera la presunción; y además, los indicios que se arrimen al proceso deben ser de aquellos de los cuales puedan colegirse con visos de certeza relaciones de afecto, por ejemplo, la convivencia o cercanía, y no solo formales, entre víctima directa e indirecta ${ }^{77}$.

75 M'CAUSLAND SÁnChEz. Tipología y reparación del daño inmaterial. Comentarios críticos sobre la jurisprudencia reciente, cit., 74.

76 Lahe, J. y Kull, I. Compensation of Non-pecuniary Damage to Persons Close to the Deceased or to the Aggrieved Person. En International Comparative Jurisprudence, Mykolas Romeris University. 2, 2016, 1-7. Disponible en: http://dx.doi.org/10.1016/j.icj.2016.03.001

77 "Pero como nuestra jurisprudencia se contenta con la prueba del vínculo de parentesco entre los demandantes y la víctima directa, y con base en ello otorga un determinado monto indemnizatorio, necesariamente cae en la arbitrariedad": TAMAYO JARAMILLO. Tratado de responsabilidad civil, cit., 809. 
Finalmente, el juez, como director del proceso, puede decretar pruebas de oficio con el fin de que la decisión de reconocer o no el perjuicio moral a favor de alguna víctima indirecta, a través de la presunción, atienda las particularidades del caso. Al respecto, el maestro Hinestrosa expresó:

De lo cual se infiere que no basta la presunción de aflicción o pesar, fundada en la presencia de vínculos de parentesco o de alianza, para decretar la indemnización de un daño moral suponible y supuesto en atención a ellos, sino que el juez, en ejercicio de sus poderes de dirección formal y material del proceso, que hoy le son reconocidos por el ordenamiento procesal civil, y en cumplimiento de los deberes ajenos a ellos, debe, si por otras vías no apareciere dilucidado el asunto en el proceso, decretar de oficio la práctica de pruebas (art. 180 c.p.c.) enderezadas a esclarecer la efectividad y aun la intensidad de esos afectos o sentimientos ${ }^{78}$.

El juez, sobre la base de la multiplicidad de indicios, puede realizar la presunción o, por el contrario, negar reconocimiento por daño moral a quien únicamente por el parentesco sí sería acreedor; o, inclusive, podría reconocer un monto indemnizatorio diferente al preestablecido, esto en atención a la verdadera intensidad de las relaciones, de afecto y familiares, entre víctima directa e indirecta ${ }^{79}$.

\section{CONCLUSIÓN}

En la jurisdicción contencioso administrativa colombiana existe una línea jurisprudencial a partir de la cual se presume el daño moral de cónyuge y parientes hasta el segundo grado de parentesco por consanguinidad y civil, cuando el reclamo tiene origen en la muerte, lesión o privación injusta de la libertad de la víctima directa.

78 Hinestrosa, F. Escritos varios. Apreciación del daño moral. Bogotá: Universidad Externado de Colombia, 1983, 725 .

79 "Pero la intensidad en las relaciones no surge automáticamente de un parentesco. No se es acreedor al máximo de indemnización por perjuicios morales por el hecho de ser padre, hijo o cónyuge, sino porque se rompió una relación sentimental, afectiva, no simplemente formal, entre la víctima y el perjudicado. Por tanto, si bien por el simple parentesco se presume la existencia del perjuicio moral y al perjudicado le basta probar el parentesco y la convivencia para que surjan los perjuicios morales, es posible que en el proceso dicha presunción se destruya o que se modifique en su intensidad. Por ello, el demandado puede demostrar que la relación sentimental que el parentesco hacía presumir entre víctima y perjudicado no existía o que estaba notoriamente deteriorada. Y el juez puede abstenerse de reconocer la indemnización de los perjuicios morales o tasarlos en sumas muy diferentes del máximo fijado por la ley: la regulación de los perjuicios morales no es automática como equivocadamente se cree entre nosotros: no basta probar el parentesco para que se fije el máximo establecido por la norma; las circunstancias modificadoras de la relación afectiva influyen necesariamente en el monto que debe fijar el fallador": MARTínEZ Rave, G. y Martínez Tamayo, C. Responsabilidad civil extracontractual. 11. a ed. Bogotá: Temis, 2003,354 a 356. 
Esta presunción, que se soporta en el parentesco como indicio y en las relaciones de familia como regla de la experiencia, debe ser revisada y reevaluada por el Consejo de Estado, toda vez que, como está diseñada, conduce a que su aplicación deje en entredicho la certeza del daño como condición de su reparación, además de que es discriminatoria frente a modelos de familia no tradicionales.

En efecto, el parentesco es respecto del daño moral simplemente un indicio contingente, pues de aquel no se deducen relaciones de afecto, además de que la regla de la experiencia se fundó en un concepto tradicional de familia que no recoge diversos modelos familiares aceptados actualmente por el ordenamiento jurídico.

Finalmente, como solución, se plantea que la presunción sea decretada por el juez en cada caso concreto atendiendo las particularidades del mismo. Para ello es necesario que la presunción se funde en varios indicios atendiendo la regla del artículo 252 CGP, y no en uno solo como actualmente viene sucediendo, debiendo el juez incluso hacer uso de su poder de decreto oficioso de pruebas para dilucidar cualquier duda respecto de la causación del perjuicio.

\section{REFERENCIAS}

\section{Libros y revistas}

Azula Camacho, J. Manual de derecho procesal. T. vi. Pruebas judiciales. Bogotá: Temis, 2015.

Cárdenas Villarreal, H. y González Vergara, P. Notas en torno a la prueba del daño moral: un intento de sistematización. En Revista Facultad de Derecho y Ciencias Políticas. Vol. 37, n. ${ }^{\circ}$ 106, 2007, 213-237.

CORTÉs, É. Responsabilidad civil y daños a la persona: el daño a la salud en la experiencia italiana, ¿un modelo para América Latina? Bogotá: Universidad Externado de Colombia, 2009.

Devis Echandía, H. Teoría general de la prueba judicial. T. II. Bogotá: Temis, 2012.

Diez Schwerter, J. L. El daño extracontractual. jurisprudencia y doctrina. Santiago: Jurídica de Chile, 1998.

Femenias Salas, J. Notas sobre la prueba del daño moral en la responsabilidad civil. En Revista Derecho y Humanidades. N. ${ }^{\circ}$ 17, 2011, 31-46.

Gómez Pomar, F. y Marín García, I. (dirs.). El daño moral y su cuantificación. En Domínguez Martínez, P., Daño moral derivado de muerte y de lesiones corporales. Barcelona: Bosch, 2015.

González Medina, D. A. Familia e igualdad. Dos conceptos relacionados a la luz de la Constitución Política de 1991. En Revista Derecho del Estado. ‥ 19, 2006, 71-86. 
Henao Pérez, J. C. El daño: análisis comparativo de la responsabilidad extracontractual del Estado en derecho colombiano y francés. Bogotá: Universidad Externado de Colombia, 1998.

Henao Pérez, J. C. y Ospina Garzón, A. F. (eds.). La responsabilidad extracontractual del Estado. En XVI Jornadas Internacionales de Derecho Administrativo. Bogotá: Universidad Externado de Colombia, 2015.

Hinestrosa, F. Escritos varios. Apreciación del daño moral. Bogotá: Universidad Externado de Colombia, 1983.

Hinestrosa, F. Hacia un derecho de familia del siglo XXI. En Revista de Derecho Privado, Universidad Externado de Colombia. N. ${ }^{\circ}$ 4, 1999.

Hinestrosa, F. Tratado de las obligaciones. 3. a ed. Bogotá: Universidad Externado de Colombia, 2007.

Hunter Ampuero, I. La prueba del daño moral. Memoria para optar al grado de licenciado en Ciencias Jurídicas y Sociales, Universidad Austral de Chile. Valdivia, 2005.

Котегсн, M. La reparación del daño como mecanismo de tutela de la persona: del daño a la salud a los nuevos daños extrapatrimoniales. Bogotá: Universidad Externado de Colombia, 2012.

Lahe, J. y Kull, I. Compensation of Non-pecuniary Damage to Persons Close to the Deceased or to the Aggrieved Person. En International Comparative Jurisprudence, Mykolas Romeris University. 2, 2016, 1-7.

Leguisamón, V. E. Las presunciones judiciales y los indicios. 2. ed. Santa Fe: RubinzalCulzoni, 2006.

Martínez Rave, G. y Martínez Tamayo, C. Responsabilidad civil extracontractual. 11. ${ }^{a}$ ed. Bogotá: Temis, 2003.

M'Causland Sánchez, M. C. Responsabilidad objetiva del Estado: tendencias, deseos y realidades. En Henao, J. C. y Ospina Garzón, A. F. (eds.), La responsabilidad extracontractual del Estado. XVI Jornadas Internacionales de Derecho Administrativo. Bogotá: Universidad Externado de Colombia, 2015.

M'Causland Sánchez, M. C. Tipología y reparación del daño no patrimonial. Situación en Iberoamérica y en la jurisprudencia de la Corte Interamericana de Derechos Humanos. Bogotá: Universidad Externado de Colombia, 2013.

M'Causland Sánchez, M. C. Tipología y reparación del daño inmaterial. Comentarios críticos sobre la jurisprudencia reciente. Bogotá: Universidad Externado de Colombia, 2015.

Monroy Cabra, M. G. Derecho de familia, infancia y adolescencia. Bogotá: Librería Ediciones del Profesional, 2014.

Navia Arroyo, F. Del daño moral al daño fisiológico, ¿una evolución real? Bogotá: Universidad Externado de Colombia, 2000. 
Pinzón Muñoz, C. E. El derecho de daños en la responsabilidad extracontractual del Estado. Bogotá: Doctrina y Ley, 2015.

Rojas Quiñones, S. El daño a la persona y su reparación. Sobre la teoría general, los sistemas de cuantificación y los casos difíciles. Bogotá: Grupo Editorial Ibáñez, 2015.

Rueda Prada, D. La indemnización de los perjuicios extrapatrimoniales en la jurisdicción de lo contencioso administrativo de Colombia. Tesis de maestría en Derecho, Universidad del Rosario. Bogotá, 2014.

Tamayo Jaramillo, J. Tratado de responsabilidad civil. T. 2. 2. ed. Bogotá: Legis, 2015.

Vergara Bezanilla, J. P. La mercantilización del daño moral. En Revista de Derecho del Consejo de Defensa del Estado. N. . 1, 2000, 67-77.

\section{Recursos electrónicos}

Aldeas Infantiles sos Colombia. Abandono: un delito injustificable, 2016. Disponible en: http://www.agenciapandi.org/wp-content/uploads/2015/Reportajes/Abandono_Ninez.pdf

Child TRends. World Family Map. Mapa de los cambios en la familia y consecuencias en el bienestar infantil, 2015. Disponible en: http://worldfamilymap.ifstudies.org/2015

Instituto Colombiano De Bienestar Familiar. Entornos protectores. Módulo 5: Vinculación afectiva. 2. ${ }^{a}$ ed. 2017. Disponible en: https://www.icbf.gov.co/sites/default/files/ procesos/pu5.mo9_.pp_modulo_5_vinculacion_afectiva_v2.pdf

\section{Jurisprudencia}

\section{Consejo de Estado}

Sala de lo Contencioso Administrativo, Sección Tercera. Sentencia del 23 de abril de 1981, exp. 2040.

Sala de lo Contencioso Administrativo, Sección Tercera. Sentencia dle 8 de agosto de 1985 , exp acumulados 2277, 2283, 2290, 2292 y 2295.

Sala de lo Contencioso Administrativo, Sección Tercera. Sentencia del 6 de febrero de 1986, exp. 3575 .

Sala de lo Contencioso Administrativo, Sección Tercera. Sentencia del 15 de septiembre de 1988, exp. 5212.

Sala de lo Contencioso Administrativo, Sección Tercera. Sentencia del 26 de enero de 1989, exp 5274.

Sala Plena de lo Contencioso Administrativo. Sentencia del 7 de febrero de 1989, exp. S-067.

Sala Plena de lo Contencioso Administrativo. Sentencia del 18 de mayo de 1990, exp. S-121. 
Sala de lo Contencioso Administrativo, Sección Tercera. Sentencia del 17 de julio de 1992, exp. 6750.

Sala de lo Contencioso Administrativo, Sección Tercera. Sentencia del 20 de agosto de 1993, exp. 7881.

Sala de lo Contencioso Administrativo, Sección Tercera. Sentencia del 21 de septiembre de 2001, exp. 11766.

Sala de lo Contencioso Administrativo, Sección Tercera. Sentencia del 2 de septiembre de 2009, exp. 17997.

Sala de lo Contencioso Administrativo. Sección Tercera, Subsección A. Sentencia del 9 de marzo de 2011, exp. 18587.

Sala de lo Contencioso Administrativo, Sección Tercera, Subsección A. Sentencia del 24 de marzo de 2011, exp. 18956.

Sala de lo Contencioso Administrativo, Sección Tercera, Subsección B. Sentencia del 30 de junio de 2011, exp. 19836.

Sala de lo contencioso Administrativo, Sección Tercera, Subsección C. Sentencia del 7 de julio de 2011, exp. 20835.

Sala de lo Contencioso Administrativo, Sala Plena de la Sección Tercera. Sentencia del 23 de agosto de 2012, exp. 24392.

Sala de lo Contencioso Administrativo, Sección Tercera, Subsección B. Sentencia del 30 de enero de 2013, exp. 25583.

Sala de lo Contencioso Administrativo, Sección Tercera, Subsección A. Sentencia del 29 de junio de 2013, exp. 29452.

Sala de lo Contencioso Administrativo, Sección Tercera, Subsección B. sentencia del 29 de agosto de 2013, exp. 29707.

Sala de lo Contencioso Administrativo, Sección Tercera, Subsección B. Sentencia del 27 de septiembre de 2013, exp. 29604.

Sala de lo contencioso Administrativo, Sala Plena de la Sección Tercera. Sentencias del 28 de agosto de 2014, exp. 26251, 27709, 28804, 28832, 31170, 31172, 32988, 36149.

Sala de lo Contencioso Administrativo, Sección Tercera, Subsección A. Sentencia del 29 de octubre de 2014, exp. 29626.

Sala de lo Contencioso Administrativo, Sección Tercera, Subsección A. Sentencia del 25 de enero de 2017, exp. 45057.

Sala de lo Contencioso Administrativo, Sección Tercera, Subsección A. Sentencia del 26 de abril de 2017, exp. 44451.

Sala de lo Contencioso Administrativo, Sección Tercera, Subsección A. Sentencia del 10 de mayo de 2017, exp. 44080. 


\section{Corte Suprema de Justicia}

Sala de Casación Civil. Sentencia de 21 de julio de 1922

Sala de Casación Civil. Sentencia de 22 de agosto de 1924.

Sala de Casación Civil. Sentencia de 5 de agosto de 2014. Exp. 11001310300320030066001.

\section{Corte Constitucional}

Sentencia C-814 de 2001.

Sentencia T-606 de 2013.

Sentencia T-070 de 2015. 